\title{
LEGAL STATUS OF WARSHIP WRECKS FROM WORLD WAR II IN INDONESIAN TERRITORIAL WATERS (INCIDENT OF H.M.A.S. PERTH COMMERCIAL SALVAGING)
}

\author{
Senada Meskin \\ Post Graduate Student, Australian National University Canberra \\ Email: senada.meskin@gmail.com
}

\begin{abstract}
Second World War was one of the most devastating experiences that World as a whole had to endure. The war left so many issues unhandled, one such issue is the theme of this thesis, and that is to analyze legal regime that is governing sunken warships. Status of warship still in service is protected by international law and national law of the flag State, stipulating that warships are entitled to sovereign immunity. The question arises whether or not such sovereign immunity status follows warship wreck? Contemporary international law regulates very little considering 'sovereign wrecks', but customary international law, municipal court decisions and State practices are addressing issues quite profoundly, stating that even the warship is no longer in service it is still entitled to sovereign immunity status. HMAS Perth is Australian owned warship whose wreck current location is within Indonesian Territorial Sea. Recent reports show that commercial salvaging has been done, provoking outrage amongst surviving HMAS Perth's naval personnel and Australian historians. In order to acquire clear stand point on issue of Sovereign Wrecks legal status, especially of HMAS Perth's wreck, an in-depth analysis of legal material is necessary.
\end{abstract}

Keywords: Territorial Waters, Warship, Warship Wreck, Salvage

\section{INTRODUCTION}

Sea going vessels has been used as a means of transport and warfare as long as there is known history. The fact that $70 \%$ of our earth's surface are water ${ }^{1}$ makes these vessels important even today. Warships have played crucial role in the outcome of Second

${ }^{1}$ Student Atlas of the World, National Geographic Society, Washington DC, 2009, page 26.
World War ${ }^{2}$, and Indonesia, which waters, many countries used as passage, had its part as well.

\footnotetext{
2 World War Two started in 1939 when Hitler invaded Poland on 1 September, and Britain and France declared war to Germany two days later. The war ended 1945 when Russians reached Berlin and Hitler committed suicide. On the other side of the world USA dropped Atomic Bombs on Hiroshima and Nagasaki which ended war in eastern part of the globe. Bruce Robinson, World War Two: Summary Outline of Key Events(online), http://www.bbc .co.uk/history/worldwars/wwtwo/, (01 May 2014).
} 
During Second World War waters of Indonesia's archipelago were mainly used by warships belonging to Imperial Japanese Navy and Allay forces. Japan's intent was to expand its empire by occupying territories of former British and Dutch colonies, and Australia being neighboring country felt threatened. America, Britain, Dutch and Australia (ABDA) would face Japanese Navy fleet in more than one occasion, ${ }^{3}$ trying to prevail in war for the Pacific. However, the strength of Japanese navy fleets was not to be underestimated. The majority of these battles was won by Japan, including the battle for Sunda Strait on 28 February $1942,{ }^{4}$ causing ABDA ships to sink, including HMAS Perth. ${ }^{5}$

HMAS Perth was Royal Australian Navy commissioned warship, build in Portsmouth, England. Her primarily duty was to patrol and provide an escort to ships over Australian coastline, when her Captain got new orders, which took HMAS Perth to Mediterranean, where she joined the 7 th

\footnotetext{
${ }^{3}$ Battle of Java sea on 27 February 1942; Battle of the Coral Sea, 7-9 may 1942; Battle of Layte Gulf 23-25 October 1944; Battle of Philippine sea 19-20 June 1944. History Year by Year, Dorling Kinderslay Limited, Great Britain, 2011, Page 394395

${ }^{4}$ Ibid.

5 Australian Navy, HMAS Perth (I) (online), http://www.navy.gov.au/hmas-perth-i (04 April 2014).
}

Cruiser Squadron under Admiral Andrew Cunningham's command, ${ }^{6}$ and this was to be her first war experience. HMAS Perth promptly returned to Australia, resuming it's primarily duty, which will take her to Indonesian Archipelago where she will become part of ABDA forces, trying to repeal advance of Japanese Navy. The Sunda Strait battle will prove itself fatal for HMAS Perth and USS Houston. Both ally ships engaged Japanese destroyer warships, ships generally larger and better armed than those operated by ally forces, causing both ships sank around midnight. HMAS Perth sank at 00.25 on 1 March 1942, together with 350 of 671 its Naval Personnel. Rest of the crew survived only to be captured, who, upon the end of the war, 214 of them, were repatriated where rest died in captivity. ${ }^{7}$

Today HMAS Perth lies at 35 (thirty five) meters deep of Sunda Strait shallow waters. Recent reports show that the condition of the ship is such that there is evidence of commercial salvaging done, where many of the ship parts are missing, for which is known that they were intact at

\footnotetext{
${ }^{6}$ Donald Summerville \& Ian Westwell, First and Second World War, Lorenz Books, London, page 307.

${ }^{7}$ Ibid.
} 
the time of ships sinking. ${ }^{8}$ Australian Survivors, historians and Defense personnel have been horrified to discover that the wreck of HMAS Perth is being destroyed by commercial salvagers. ${ }^{9}$

International law attributes sovereign immunity status to warships, ensuring that these ships are not to be "subject to seizure, arrest or detention by any legal process, nor to any proceedings in rem." ${ }^{10} \mathrm{~A}$ warship is a seagoing vessel owned by States armed forces, wearing clear external marks, Commanded by an officer and manned by naval personnel. ${ }^{11}$ HMAS Perth, at the time she was commissioned by Australian Navy fulfilled all condition of a warship, thus she was entitled on sovereign immunity status. Whether or not such status still follows her

\footnotetext{
${ }^{8}$ All 4" Gun Turrets are missing. It is known that S2 4" received a direct hit and was blown over the side. It is not known what happened to the other three turrets. Many items have apparently been removed from the wreck by salvagers. Photos Of The Perth \& HoustonWrecks Today (online)http://www.perthone.com/pwre.html, (06 April 2014).

9 Linton Besser, Dan Oakes and Norman Hermant,HMAS Perth: WWII warship grave stripped by salvagers (online), http://www.abc.net.au/news/2013-12-13/outrage-aswarship-grave-stripped-by-salvagers $/ 5156320,(21$ of April 2014).

${ }^{10}$ Article 3, Paragraph (1), International Convention For The Unification Of Certain Rules Concerning The Immunity Of State-Owned Ships 1926.

${ }^{11}$ Article 29, United Nations Convention on Law of the Sea 1982 (UNCLOS 1982).
}

wreck is one of the questions this paper will try to analyze.

Location of the wreck further complicates legal status of HMAS Perth. As is regulated in UNCLOS 1982, territorial sea is an adjacent belt of sea, ${ }^{12}$ governed by sovereignty of coastal State, ${ }^{13}$ which is incidental and does not need to be established. $^{14}$ Such sovereignty is only limited by innocent passage, which is "right of a foreign vessel to travel to a country's maritime belt without paying a tall". ${ }^{15}$ Every action, such as for example salvaging efforts of a wreck, has to be governed by coastal States national laws.

Clearly the conflict of valid states jurisdiction occurs in case of HMAS Perth wreck. Indonesian sovereignty extends over an area where HMAS Perth's wreck lies giving Indonesia exclusive rights over its territorial sea, while Australia as an identifiable owner of its 'sovereign wreck' has a valid right to claim the wreck based on sovereign prerogative. This paper will analyze closely what sort of rights and obligations both state have in regard to

\footnotetext{
${ }^{12}$ Ibid., Article 2 paragraph (1).

${ }^{13}$ Ibid.

${ }^{14}$ Aust, Anthony,Handbook of International Law, Cambridge University Press, New York, 2005, page 302.

${ }^{15}$ Bryan A. Garner, Black's Law Dictionary, Thomson Reuters, USA, 2009, page 860.
} 
HMAS Perth's wreck, and give suggestion on what steps should be taken to reach a mutually beneficiary solution.

\section{METHODE OF RESEARCH}

This writing use juridical-normative method, including reviewing and analyzing the rules of international law concerning The Law of the Sea, protection of warship wrecks and laws considering salvaging, as well conducting a comprehensive analysis of Indonesian National Law.

Further research will be conducted over national legal acts in Indonesia and comparative study to Australian legislature products considering warship wrecks, their protection and salvage. The writer has intention to address municipal court decisions of international character as well, to find out what sort of law was used to resolve a case considering salvaging of warship wrecks.

The approach in this paper is the Statute Approach, which in this research will explore the nature of legal mattersformal and Case Approach in-depth analysis of the cases. Hence law material used more emphasis on secondary data, which in this case comes from the material obtained, such as primary legal materials and secondary legal materials.

\section{RESULT AND DISCUSSION}

\section{A. Legal Status of HMAS Perth's Wreck}

\section{a. Records of HMAS Perth's Service}

HMAS Perth English made Light Cruiser, made and assembled in Portsmouth Naval Dockyard, and commissioned into the Royal Navy as HMAS Amphion on 15 June 1936. Three years later she was bought by the Australian Government and was commissioned into Royal Australian Navy (RAN) on 29 June 1939. Cruiser Amphion was officially renamed as HMAS Perth on 10 July 1939 in a ceremony led by Princess Marina, The Duchess of Kent. ${ }^{16}$ She reached Australia on 31 March 1940 and HMAS Perth got "engaged on patrol and escort duties in Australian waters." 17

HMAS Perth got new orders to escort seventh Middle East Convoy, US 7, on 28 November 1940, accompanied by ships of Royal Navy, Royal Australian

\footnotetext{
${ }^{16}$ Anonimus, HMAS Perth (I) (online), Navy, http://www.navy.gov.au/hmas-perth-i (03 July 2014). ${ }^{17}$ Loc. Cit., AWM.
} 
Navy, and Royal Indian Navy. A first real war experience that HMAS Pert had was when she joined Mediterranean Fleet, 7th Cruiser Squadron under Admiral Andrew Cunningham's command. HMAS Perth was involved in the evacuations of Crete and Greece in April and May 1941, "in the course of which she was badly damaged by bombing."18 HMAS Perth sailed towards Alexandria for repairs. On completion of repairs she joined Fleet units of Syrian coast in June 1941 and got involved in offensive sweep to intercept Vichy warships. ${ }^{19}$ In August 1941 HMAS Perth rejoined Royal Australian Navy and, ${ }^{20}$ and on 29 January 1942 HMAS Perth together with several other Australian cruisers was transferred to Australian and New Zealand Army Corps under command of US navy. ${ }^{21}$ Escort of military convoy MS4 for passage to Singapore was its duty under US command, and it got detached from MS4 after fall of Singapore, joining Western Striking Force of American British Dutch Australian (ABDA) Command in East Indies.

\footnotetext{
${ }^{18}$ Loc.Cit., AWM.

19 Geoffrey B Mason, Service History of Royal Navy Warships in World War II (online), http://www.naval-history.net/xGM-Chrono-06CL-

Perth.htm, (05 Jully 2014).

${ }^{20}$ Ibid.

${ }^{21}$ Ibid.
}

HMAS Perth arrived at Batavia on 24 February 1942 where she got attacked by Japanese aircraft without sustaining any damage. $^{22}$ She joined combined striking force "comprising Dutch cruisers De Ruyter and Java, HMS Electra, US Cruiser Houston, HM Destroyers Electra, Encounter and Jupiter Dutch Destroyers De Witte and Kortenaer, US Destroyers John D Edwards Alden, and John DF Ford",23, led by Dutch Admiral Karel Doorman. Allied forces were defeated in Battle of Java Sea on 27 February $1942^{24}$ where a large number of destroyers sunk. ${ }^{25} \mathrm{HMAS}$ Perth and USS Houston managed to break off and arrived to Tanjung Priuk on 28 February 1942 to refuel. Both ships got orders to escape through the Sunda strait and sail to Tjilatap on the south coast of Java. Allied intelligence that was received by HMAS Perth and USS Houston was that strait was clear of the enemy fleet, but this intelligence was at least 24 hours late, ${ }^{26}$ causing both ships to clash with Japanese invasion force

\footnotetext{
${ }^{22}$ Loc. Cit., Navy.

${ }^{23}$ Loc. Cit., Naval History.

${ }^{24}$ Loc. Cit., Donald, page 335.

${ }^{25}$ "The Dutch cruisers were sunk and Exeter badly damaged, while most of the destroyers were sunk or withdrew as their torpedoes were exhausted." Loc. Cit., AWM.

${ }^{26}$ Loc.cit., PerthOne.
} 
assigned for western Java. ${ }^{27}$ The enemy attacked from all sides, but HMAS Perth sustained little damage. Realizing that ship is out of ammunition, Captain H.M.L Waller, of HMAS Perth attempted to force a passage to Sunda strait, when ship got striked by three torpedoes and consequently sank at 00.25 on 1 March $1942 .{ }^{28}$ "Of the Perth's company of 686, which included four civilians canteen staff and six RAAF personnel for operating and servicing her aircraft, only 218 (including one civilian and two RAAF) were eventually repatriated; the remainder was killed during, or soon after, the action, or died as prisoners of war." 29

\section{b. Warship Status and Sovereign Immunity of HMAS Perth}

Warship is defined as "a ship belonging to the armed forces of a State bearing the external marks distinguishing such ships of its nationality, under the command of an officer duly commissioned by the government of the State and whose name appears in the appropriate service list or its equivalent, and manned by a crew which is under regular armed forces discipline. ${ }^{30}$ The Australian Government purchased HMAS Perth, and commissioned

\footnotetext{
${ }^{27}$ Loc.cit., AWM.

${ }^{28}$ Loc.cit., AWM.

${ }^{29}$ Ibid.

${ }^{30}$ Supra Note 13.
}

her to Royal Australian Navy on 29 June 1939, thus the condition of belonging to armed forces of a State is fulfilled. Further, it needs to bear distinguishable external marks stating the nationality of a ship. By looking at several pictures from era at which HMAS Perth sailed as well as official data collected, it is visible that she belonged to Royal Australian Navy. ${ }^{31}$ Than ship needs to be under command of an officer, commissioned by government. On 24 October 1941 Captain Hector Macdonald Laws Waller assumed command over HMAS Perth. Captain Waller joined Royal Australian Navy in 1913 by entering Royal Australian Naval College, and graduated in 1917. ${ }^{32}$ Personnel on board of HMAS Perth were in total 681 out of which 671 were man who were a part of the navy, as naval personnel. HMAS Perth before it sank was in service of the Australian Government, was a navy owned ship, bearing clear nationality marks, under command of an

\footnotetext{
${ }^{31}$ A Brief History of the Australian Cruiser HMAS Perth (online), http://www.perthone.com /perth.htm, (19 July 2014); Australian Navy, HMAS Perth (I) (online), http://www.navy.gov.au /hmas-perth-i, (19 July 2014); Australian War Memorial, The Loss of HMAS Perth, 1 March 1942 (online), http://www.awm.gov.au/encyclopedia/perth/loss/, (19 July 2014).

${ }^{32}$ Captain Hector MacDonald Laws Waller (online), http://defence-honours-tribunal.gov .au/wpcontent/uploads/2013/01/AF13050626.pdf, (05 July 2014).
} 
officer, and manned by naval personnel, thus HMAS Perth had a status of a warship.

The use of warships in general is of non-commercial nature. Such fact bestowed sovereign immunity on the warship as regulated in Article 32 of UNCLOS 1982. Sovereign immunity means that a warship shall not be "subject to seizure, arrest or detention by any legal process, nor to any proceedings in REM" ${ }^{33}$ Historical records show the fact that in the short period that HMAS Perth was a part of Royal Australian Navy, she was used for non-commercial purpose by Australian Government, entitling HMAS Perth on sovereign immunity status.

\section{c. HMAS Perth as a Sovereign wreck and Loss of Sovereign Wreck Status}

Warship used by a State for noncommercial purpose at the time of sinking has 'sovereign wreck "status. ${ }^{34}$ UNCLOS 1982 is silent on sovereign wrecks. IMO Convention on Salvage 1989 (Convention 1989) stipulates that sunken warships and state owned vessels are entitled to sovereign immunity, that this convention shall not

\footnotetext{
${ }^{33}$ Article 3, Paragraph (1), Convention 1926.

${ }^{34}$ Craig JS Forrest, Culturally and Environmentally Sensitive Sunken Warships (online), Australian and New Zeland Maritime Law Journal, https://maritimejournal.murdoch.edu.au/ index.php/maritimejournal/article/view/181, (10 July 2014), 2012.
}

apply if State that owns such vessel decides otherwise, $^{35}$ implying that sovereign immunity from the period at which these vessels were in service, applies to the wreck as well. The UNESCO Convention on the Protection of Underwater Cultural Heritage from 2001 (Convention 2001) regulates considering State vessels as underwater cultural heritage, ${ }^{36}$ retaining stand point that sovereign immunity status still applies. ${ }^{37}$ HMAS Perth's status, analyzed in regard of Convention 1989 and Convention 2001 is a sovereign wreck, thus no action directed towards the wreck is allowed without explicit permission of the wreck's owner, in this case Australia.

Nevertheless, sovereign wreck could lose hers sovereign immunity status if:

1) It was abandoned by the State $^{38}$ There are two theories proposed, first that State expressly abandoned ownership over state vessel, and second, that abandonment is implied through State's inaction and passing of time. ${ }^{39}$ Expressive abandonment is what is generally accepted by

\footnotetext{
${ }^{35}$ Article 4, Paragraph (1) \& (2), IMO Convention 1989.

${ }^{36}$ Article 1, Number (8) Convention 2001.

${ }^{37}$ Ibid., Article 2, Number (8).

${ }^{38}$ Loc. Cit., Craig.

${ }^{39}$ Ibid.
} 
national $\operatorname{laws}^{40}$, as well is seen though state practices and municipal courts decisions. ${ }^{41}$ Implied abandonment on the other hand is rejected by majority of states firmly claiming that sovereign right over warship wrecks is neitherextinguished by passing of time nor States inaction. ${ }^{42}$

2) Taken by mutinous crew - UNCLOS 1982 regulates that acts of piracy done by such a warship shall be "assimilated as acts committed by a private ship" ${ }^{43}$, implying that sovereign immunity is lost.

40 Abandoned Shipwreck Act of 1987 of United States.

${ }^{41}$ United States of America v. Richard Steinmetz (973 F. 2d 212 - 1992); Baltimore, Crisfield \& Onancock, Inc., v. United States of America, (140 F. 2d 230 1944); Sea Hunt, Inc. v Unidentified Shipwrecked Vessel or Vessels (221 F.3d 634 - 2000); Odyssey Marine Exploration Inc. v Unidentified shipwrecked vessel (No10-1037 - 2011).

${ }^{42}$ Communication from the UK Foreign and Commonwealth Office, July 4, 2003; Communication from the French Foreign Ministry, November 28, 2003; Communication from the German Foreign Ministry, October 30, 2003; Communication from the Government of Japan, September 13, 2003; Communication from the Government of the Russian Federation, October 3, 2003; Embassy of Spain, Washington, DC, Note No. 128, December 19, 2002. US Departement of State (public Notice 4614), Office of Ocean Affairs; Protection of Sunken Warships, Military Aircraft and Other Sunken Government Property (online), http://www.gpo. gov/fdsys/pkg/FR-2004-02-05/pdf/04-2488.pdf, (09 July 2014).

${ }^{43}$ Article 102, UNCLOS 1982.
3) The hostaltakeover by enemy forces

- The transfer of title occurs trough capture of warship in the ongoing battle before it actually sinks. ${ }^{44}$

Historical records show that HMAS Perth sank with her crew, it was not taken over by the enemy nor her crew was mutinous, thus HMAS Perth's sovereign wreck status is not lost. Regarding abandonment there are no records that Australia has abandoned HMAS Perth's Wreck, on contrary, recent statement made by the Department of Defense imply otherwise. $^{45}$

\section{d. HMAS Perth as a War Grave}

\footnotetext{
${ }^{44}$ Rob Regan, When Lost Liners Become Found: An Examination of the Effectiveness of Present Maritime Legal and Statutory Regimes for Protecting Historic Wrecks in International Waters with Some Proposals for Change (online), Tulane Maritime Law Journal, Volume 29, http://www.rmsrepublic.com/reference/TulaneLawJournal.pdf, (21 July 2014), 2005, page 336; Admiral Nakhimov incidet - Russian warship captured by Japan, Loc.Cit. Craig.

45، The Chief of Navy, Vice Admiral Ray Griggs has written to his counterpart the Chief of the Indonesian Navy, Admiral Dr. Marsetio on this issue. The Australian embassy Defence staff in Jakarta continues to work on this with Indonesian officials. [...] As modern custodians of that heritage no one is more passionate than Navy in preserving the sites where our war dead still lie." Australia's Departement of Defence, Media Reporting of Salvage Activity on the Wreck of HMAS Perth I (online), http://news.defence.gov.au/2013/12/14/mediareporting-of-salvage-activity-on-the-wreck-of-hmasperth-i/, (09 July 2013).
} 
The Contemporary International Law does not specifically regulates War Graves, but under The Geneva Conventions for the protection of war victims of 12 August 1949 and Additional Protocols of 8 June 1977 (Convention 1949), is stipulated obligation to the Parties to treat their dead with respect, ${ }^{46}$ properly register them ${ }^{47}$ and if possible conduct medical examination. ${ }^{48}$

Great Britain government has "attached particular historical and sentimental value to the remains of the soldiers who went down with the ship"49 by adopting the Protection of Military Remains Act 1986. This Act forbids any excavation or diving or salvage, ${ }^{50}$ even if such operation is conducted in international water, a person is held liable based on extraterritorial jurisdiction. ${ }^{51}$ United States navy has clear policy considering warship wrecks, especially those that have human remains on board. It stated that "salvers should not presume that sunken U. S. Warships have been abandoned by the United States. Permission must be granted by the United

${ }^{46}$ Article 18, Convention 1949.

${ }^{47}$ Ibid., Article 19.

${ }^{48}$ Ibid., Article 20.

${ }^{49}$ Jason R. Harris, The Protection of Sunken Warships as Gravesites at Sea, Ocean and Coastal Law Journal, Volume 7.1, page 124.

${ }^{50}$ Section 2, Paragraph (2), Protection of Military Remains Act 1986.

${ }^{51}$ Ibid., Section 3, Paragraph (1), Letters (a) \& (b).
States to salvage sunken U.S. warships, and as a matter of policy, the United States Government does not grant such permission with respect to ships that contain the remains of deceased servicemen $[. . .]^{3,52}$

Australia and Indonesia do not have specific regulations on warship wrecks as war graves, but both states have regulations on acknowledgement and commemoration of its veterans. ${ }^{53}$ HMAS Perth sank with more than a half of its naval personnel, thus it can be presumed that some of their remains are still trapped within the wreck. Thus under both states national laws, respect should be given towards these veterans and their final resting ground protected.

\section{B. Rights And Obligations Of Indonesia And Australia Regarding Hmas Perth's Wreck}

\footnotetext{
${ }^{52}$ Robert S. Neyland, Sovereign Immunity and the Management of United States Naval Shipwrecks (online), http://www.history.navy.mil/branches/org12-7h.htm, (13 July 2014).

53 War Cabinet decision of 10 March 1922; Indonesian Government RegulationNumber 1 Year 2010 Considering the Board of Title,Mark of Services, and Mark of Honor. (Peraturan Pemerintah Republik Indonesia Nomor 1 Tahun 2010 Tentang Dewan Gelar, Tanda Jasa, Dan Tanda Kehormatan).
} 


\section{a. Territorial Sea Regime and Sovereign Immunity of Warship Wreck}

Sovereignty of the coastal State over its territorial waters is unquestionable. In case of foreign flag state, shipwrecks discovery in territorial waters, the coastal State has duty only to inform the flag state of discovery. Clearly, in such case there is a clash between two types of State jurisdictions, exclusive jurisdiction of coastal States over its territorial waters, and of Flag State over its sovereign wreck.

Innocent passage is the only limitation of coastal state's sovereignty over its territorial sea, ${ }^{54}$ thus, "the activities related to the recovery of archaeological and historical objects in these waters, therefore, are governed exclusively by the laws of the coastal State". ${ }^{55}$ However, Indonesia should do its best to preserve good neighboring relations by preventing any unauthorized action directed towards recovering HMAS Perth's Wreck. Such obligation rises out of international law principle stating Sic utere tu et alienum non

\footnotetext{
${ }^{54}$ Article 17, UNCLOS 1982.

${ }^{55}$ Moritaka Hayashi, 1996, Archeological and Historical Objects under The United Nations Convention on the Law of the Sea, Marine Policy, Vol. 20, No. 4, 1996, page 293.
}

laedas ${ }^{56}$, where Indonesia should not allow its territorial sea be to used by salvagers in their effort to salvage HMAS Perth, especially if Australia, as owner of the wreck, did not give permit. It is every State's duty to fulfill in a good faith the obligation assumed by a State, either obligation originating from general principle of international law, international rule or agreement between state. ${ }^{57}$

\section{b. Right of Salvage of HMAS Perth}

The only flag State has the exclusive right to decide whether or not there will be any salvaging operation directed towards the sovereign wreck. ${ }^{58}$ One of the reasons for retaining control over sunken state vessel is to protect important information for its national security, which could be endangered if recovery was made by another state. $^{59}$

\footnotetext{
56، Use your own property in such manner as not to injure that of another."

${ }^{57}$ Resolution adopted by the General Assembly 2625 (XXV). Declaration on Principles of International Law concerning Friendly Relations and Co-operation among States in accordance with the Charter of the United Nations.

${ }^{58}$ Article 4, Paragraph 1 IMO Convention 1989.

59 Natalino Ronizzoti, 2000, The Legal Regime ofWrecks of Warships and Other State-Owned Ship in International Law(online), Yearbook of Institute of International Law, Rhodes Session, Volume 74,http://www.idiiil.org/idiE/annuaireE/2011/Question2_Ronzitti2012-10-17.pdf, (12 July 2014).
} 
Location of warship wreck is the only factor that could influence the power that flag state has over it. The Coastal State has sovereignty over its territorial sea, thus if location of warship wreck which belong to a foreign flag State is within territorial sea of another state, such salvaging operation are governed exclusively by laws of coastal State. ${ }^{60}$ Nairobi Convention 2007 proscribes only an option for a State party to extend application of convention to its territorial sea $^{61}$, while UNESCO Convention 2001 stipulates that "Coastal States have the exclusive right to regulate and authorize activities directed at underwater cultural heritage in their internal waters, archipelago waters and territorial sea." ${ }^{\$ 2}$

\section{c. Indonesian and Australian National Legislation considering Warship Wrecks and Salvage}

1) Indonesian National

\section{Legislation}

Since year 2000 there has been growing interest in Indonesia regulating cultural and archeological objects found at

\footnotetext{
${ }^{60}$ Loc.Cit., Moritaka.

${ }^{61}$ Article 3, Paragraph (2), Nairobi Convention 2007.

${ }^{62}$ Article 7, Paragraph (1), UNESCO Convention 2001.
}

sea. ${ }^{63}$ Act of Republic Indonesia Number 11 Year 2010 considering Cultural Heritage Undang-Undang Republik Indonesia Nomor 11 Tahun 2010 Tentang Cagar Budaya (Act 11/2010) regulates considering cultural heritage on land or in water, ${ }^{64}$ giving legal protection to such heritage, which has to be established as such, if not it is not entitled on protection by this Act. HMAS Perth is not established as Cultural heritage under Act $11 / 2010$, thus enjoys no protection. Indonesian President have issued Presidential Decree Number 12 Of 2009 About Amendment to Presidential Decree Number 19 Year 2007 Concerning Appointment of National Committee and Utilization of Valuable Items originating from Sunken Ships Cargo - Keputusan Presiden Republik Indonesia Nomor 12 Tahun 2009 Tentang Perubahan Atas Keputusan Presiden Nomor 19 Tahun 2007 Tentang Panitia Nasional Pengangkatan Dan Pemanfaatan Benda Berharga Asal Muatan Kapal Yang Tenggelam (Decision 12/2009), forming National Committee

\footnotetext{
${ }^{63}$ Harry Octavianus Sofian, Permasalahan Arkeologi Bawah Air Di Indonesia Underwater Archaeology Issues InIndonesia (online), Jurnal Kapata Arkeologi, Jurnal Arkeologi Wilayah Maluku Dan Maluku Utara Balai Arkeologi Ambon, Vol. 6 No. 11, https://www.academia.edu/3540870/Permasalahan_A rkeologi_Bawah_Air_di_Indonesia_In_Indonesian_L anguage_, (21 July 2014), 2010.

${ }^{64}$ Article 1, Number (1) Act 11/2010.
} 
whose duty, amongst others, is to organize coordination of monitoring activities, supervision, and control over the process of surveying, removal and utilization valuable cargo from sunken ships. ${ }^{65}$ Ministry for Culture $^{66}$ is authorized to issue license to those individuals or organization interested in conducting survey, salvaging or usage ${ }^{67}$ of cultural heritage objects, found on land or in water, as regulated in Government Regulation of Republic Indonesia number 10 Year 1993 Considering Implementation of Act Number 5 Year 1992 considering Cultural Heritage Objects - Peraturan Pemerintah Republik Indonesia Nomor 10 Tahun 1993 Tentang Pelaksanaan UndangUndang Nomor 5 Tahun 1992 Tentang Benda Cagar Budaya (Regulation 10/1993).

Salvaging of ships in distress is regulated in Act of Republic Indonesia Number 17 Year 2008 considering Shipping - Undang-Undang Republik Indonesia Nomor 17 Tahun 2008 tentang Pelayaran (Act 17/2008). Salvaging in Indonesian waters is done towards ships wreck, and its cargo that experienced accident or it sank. ${ }^{68}$ Act 17/2008 is silent on type of ship wreck,

\footnotetext{
${ }^{65}$ Ibid., letter (d).

${ }^{66}$ Article 17, Paragraph (1), Regulation 10/1993.

${ }^{67}$ Ibid., Paragraph (2).

${ }^{68}$ Ibid., Article 204, Paragraph (1).
}

whether commercial vessels only or includes State vessels as well, nor it regulates the period of time, meaning it applies on ship that just wrecked or ship that has been in such condition for a while. The permit for salvaging in Indonesian waters is issued by Minister in charge of shipping. ${ }^{69}$

Ministry has further regulated salvaging operations through Minister of Transportation's Regulation Number PM 71 Year 2013 considering Salvage and/or Under-water Work - Peraturan Menteri Perhubungan Nomor PM 71 Tahun 2013 tentang Salvage dan/atau Pekerjaan Bawah Air (Regulation PM 71/2013). This regulation refers to ships wreck as any ship that sank, or stranded, or washed on shore and has been abandoned. ${ }^{70}$ The salvage operation, according to Regulation PM 71/2013, needs a permit from General Director $^{71}$ within Ministry of Transportation, and can be conducted only by specially licensed business. ${ }^{72}$ Obligation to remove wreck falls on wreck's owner ${ }^{73}$, if discovered wreck is unclaimed than obligation to remove wreck goes to Head of

\footnotetext{
${ }^{69} \mathrm{Ibid}$., Paragraph (2).

${ }^{70}$ Article 1, Number (3), Regulation PM 71/2013.

${ }^{71}$ Ibid., Article 6, Paragraph (1).

${ }^{72}$ Ibid., Article 3, Paragraph (1).

${ }^{73}$ Ibid., Article 13, Paragraph (1).
} 
Technical Assistance Unit of nearest Port. ${ }^{74}$ Specific salvaging of warship is not regulated within Regulation PM 71/2013, so presumably general stipulations apply.

Sovereign status of warship is acknowledged in Indonesian law. Act of Republic Indonesia Number 34 Year 2004 considering Indonesian National Army Undang-undang Republik Indonesia Nomor 34 Tahun 2004 Tentang Tentara Nasional Indonesia (Act 34/2004) regulates that one of the duties of Navy is to conduct Naval diplomacy by giving support to national policy abroad set by Indonesian government. ${ }^{75}$ Here is referred to diplomatic function of Navy recognized by International Customary Law, seen through diplomatic immunity and full sovereignty as part of every State's warship sailing foreign waters. $^{76}$

\section{2) Australian}

National

\section{Legislation}

The sovereign status of warship wrecks is recognized through international customary law as well through state practices, as previously discused, thus HMAS Perth as sovereign wreck falls under Australian Jurisdiction. While Indonesian

\footnotetext{
${ }^{74}$ Ibid., Article 15, Paragraph (3).

${ }^{75}$ Article 9, letter (c), Act 34/2004.

${ }^{76}$ Clarification of Article 9, Letter (c) of Act 34/2004.
}

law is silent on warship wrecks, Australian law is governing shipwrecks, especially wrecks of historical importance, focus solely on wrecks protection. However, Historic Shipwreck's Act 1976 stipulation considering which shipwreck is considered as historic shipwreck does not apply on HMAS Perth, because one of the condition is that shipwreck needs to be situated in Australian waters or in waters above the continental shelf of Australia, while HMAS Perth's wreck is within Indonesian Territorial Sea.

\section{d. Duty to Cooperate Under International Law}

Indonesia and Australia are both State Parties to UNCLOS $1982 .^{77}$ It is stipulated in UNCLOS 1982 that for the sake of protection of historical objects found at sea the States cooperation is advised. ${ }^{78}$ Duty to cooperate proscribed by contemporary international law does not diminish the Coastal State's exclusive jurisdiction, but it underlines general principles of international law. ${ }^{79}$

\footnotetext{
${ }^{77}$ Treatties Office Database, Summary of Treaties (online), http://ec.europa.eu/world/ agreements/ prepareCreateTreatiesWorkspace/treatiesGeneralData .do?redirect=true\&treatyId=511 (20 July 2014).

${ }^{78}$ Article 303, Paragraph 1, UNCLOS 1982.

${ }^{79}$ Loc.Cit., Craig.
} 
There are many precedents on subject of States cooperation ${ }^{80}$ regarding protection and salvaging of wrecks, where two or more states have claimed. The Agreement between the Netherlands and Australia Concerning Old Dutch Shipwrecks ${ }^{81}$ found in Western Australian coast is an example how a state can express its interest in shipwrecks once owned by it. Australia considered that passing of 300 years without any attempt to locate shipwrecks is implied abandonment, Netherlands disagreed, and the issue was resolved through agreement in $1972 .^{82}$

\section{CONCLUSION}

\footnotetext{
${ }^{80}$ “'Exchange of Notes Constituting an Agreement between the Government of the United Kingdom of Great Britain and Northern Ireland and the Government of Italy regarding the salvage of H.M.S. Spartan, Rome, Nov. 6, 1952, 158 U.N.T.S. 432 (1952); Agreement between the Government of the United Kingdom of Great Britain and Northern Ireland and the Government of the Republic of South Africa regarding the salvage of H.M.S. Birkenhead, Pretoria, Sept. 27, 1989, U.K.T.S. No. 3 (1990), Cm. 906, 60 BRIT. Y.B. INVL L. 671 (1990); Agreement between the Government of the French Republic and the Government of the United States of America concerning the wreck of the CSS Alabama, Paris, Oct. 3, 1989, T.I.A.S. No. 11687, UN, LOS BULL. No. 20, Mar. 1992"; J. Ashley Roach, Sunken Warships and Military Craft (online), http://www.history.navy.mil/branches/org12-7j.htm, (13 July 2014).

81،ZZuytdrop (1712), Batavia (1629), Vergulde Draedk (1656) and Zeewyk (1727)." Australia and the Netherlands Concerning Old Dutch Shipwrecks (online), http://www.environment. gov.au/node/20233, (09 July 2014).

${ }^{82}$ Loc.Cit., Patrick.
}

Warships are seagoing vessels entitled to sovereign immunity status. The warship wreck status is not clearly regulated under contemporary international law, but customary law and state practices agree that warship wreck is a sovereign wreck. Only state that owns sovereign wreck has the exclusive right to manage activities directed on sovereign wreck.

If the wreck was expressively abandoned by a State, or warship was taken by mutinous crew or a takeover by enemy forces before it sank, would cause a wreck to lose its sovereign status. Location of the wreck does not diminish the right of the owner State. HMAS Perth's wreck is in Indonesian territorial sea, giving Indonesia control over access while Australia still remains an owner. UNCLOS 1982 in Article 303 recommends cooperation in cases such as of HMAS Perth.

International law should formally regulate the status of sovereign wrecks. Leaning on customary law, as well on state practices, gives little if non protection towards these wrecks. Indonesia and Australia should cooperate on the issue.

\section{REFERENCES}

\section{Book}


Aust, Anthony, Handbook of International Law, Cambridge University Press, New York, 2005.

Donald Summerville \& Ian Westwell, First and Second World War, Lorenz Books, London.

Student Atlas of the World, National Geographic Society, Washington DC, 2009.

Bryan A. Garner, Black's Law Dictionary, Thomson Reuters, USA, 2009.

History Year by Year, Dorling Kinderslay Limited, Great Britain, 2011.

\section{Journal}

Craig JS Forrest, Culturally and Environmentally Sensitive Sunken Warships (online), Australian and New Zeland Maritime Law Journal, https://maritimejournal.murdoch.edu. aul index.php/maritimejournal/article/vie w/181, (10 July 2014), 2012.

Harry Octavianus Sofian, Permasalahan Arkeologi Bawah Air Di Indonesia Underwater Archaeology Issues InIndonesia (online), Jurnal Kapata Arkeologi, Jurnal Arkeologi Wilayah Maluku Dan Maluku Utara Balai Arkeologi Ambon, Vol. 6 No. 11, https://www.academia.edu/3540870/ Permasalahan

Arkeologi_Bawah_Air_di_Indonesia _In_Indonesian_Language_, (21 July 2014), 2010.

Jason R. Harris, The Protection of Sunken Warships as Gravesites at Sea, Ocean and Coastal Law Journal, Volume 7.1.

Moritaka Hayashi, 1996, Archeological and Historical Objects under The United Nations Convention on the Law of the Sea, Marine Policy, Vol. 20, No. 4, 1996,.
Natalino Ronizzoti, 2000, The Legal Regime of Wrecks of Warships and Other State-Owned Ship in International Law(online), Yearbook of Institute of International Law, Rhodes Session, Volume 74,http://www.idiiil.org/idiE/annuaireE/2011/ Question2_Ronzitti-2012-10-17.pdf, (12 July 2014).

Rob Regan, When Lost Liners Become Found: An Examination of the Effectiveness of Present Maritime Legal and Statutory Regimes for Protecting Historic Wrecks in International Waters with Some Proposals for Change (online), Tulane Maritime Law Journal, Volume 29, http://www.rmsrepublic.com/reference/TulaneLawJo urnal.pdf, (21 July 2014), 2005.

\section{Online Article}

\section{A Brief History of the Australian Cruiser} HMAS Perth (online), http://www.perthone.com /perth.htm, (19 July 2014).

Anonymous, HMAS Perth (I) (online), Navy, http://www.navy.gov.au/hmas-perthi (03 July 2014).

Australia's Department of Defense, Media Reporting of Salvage Activity on the Wreck of HMAS Perth I (online), http://news.defence.gov. au/2013/12/14/media-reporting-ofsalvage-activity-on-the-wreck-ofhmas-perth-i/, (09 July 2013).

Australian Navy, HMAS Perth (I) (online), http://www.navy.gov.au/hmas-perthi (04 April 2014).

Australia and the Netherlands Concerning Old Dutch Shipwrecks (online), http://www.environment. gov.au/node/20233, (09 July 2014). 
Australian War Memorial, The Loss of HMAS Perth, 1 March 1942 (online), http://www.awm.gov.au/encyclopedi a/perth/loss/, (19 July 2014).

Bruce Robinson, World War Two: Summary Outline of Key Events(online), http://www.bbc.co.uk/history/world wars/wwtwo/, (01 May 2014).

Captain Hector MacDonald Laws Waller (online), http://defence-honourstribunal.gov $. \mathrm{au} / \mathrm{wp}-$ content/uploads/2013/01/AF1305062 6.pdf, (05 July 2014).

Geoffrey B Mason, Service History of Royal Navy Warships in World War II (online), http://www.navalhistory.net/xGM-Chrono-06CLPerth.htm, (05 Jully 2014).

J. Ashley Roach, Sunken Warships and Military Craft (online), http://www.history.navy.mil/branche s/org12-7j.htm, (13 July 2014).

Linton Besser, Dan Oakes and Norman Hermant,HMAS Perth: WWII warship grave stripped by salvagers (online), http://www.abc.net.au/news/2013-

12-13/outrage-as-warship-gravestripped-by-salvagers/5156320,(21 of April 2014).

Robert S. Neyland, Sovereign Immunity and the Management of United States Naval Shipwrecks (online), http://www.history.navy.mil/branche s/org12-7h.htm, (13 July 2014).

Treaties Office Database, Summary of Treaties (online), http://ec.europa.eu/world/ agreements/prepareCreateTreatiesW orkspace/treatiesGeneralData.do?red

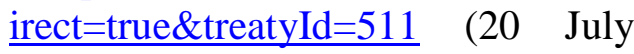
2014).

\section{Conventions and National Laws}

International Convention For The Unification Of Certain Rules Concerning The Immunity Of StateOwned Ships 1926.

Geneva Convention for the Amelioration of the Condition of Wounded, Sick and Shipwrecked Members of Armed Forces at Sea of 12 August 1949.

United Nations Convention on Law of the Sea 1982.

IMO Convention on Salvage 1989.

UNESCO Convention on Protection of the Underwater Cultural Heritage 2001.

Protection of Military Remains Act 1986 (UK)

Abandoned Shipwreck Act of 1987 (US)

Historic Shipwreck Act 1976 (Australia)

Act of Republic Indonesia Number 34 Year 2004 considering Indonesian National Army - Undang-undang Republik Indonesia Nomor 34 Tahun 2004 Tentang Tentara Nasional Indonesia.

Act of Republic Indonesia Number 17 Year 2008 considering Shipping Undang-Undang Republik Indonesia Nomor 17 Tahun 2008 tentang Pelayaran.

Act of Republic Indonesia Number 11 Year 2010 considering Cultural Heritage Undang-Undang Republik Indonesia Nomor 11 Tahun 2010 Tentang Cagar Budaya

Government Regulation of Republic Indonesia number 10 Year 1993 Considering Implementation of Act Number 5 Year 1992 considering Cultural Heritage Objects Peraturan Pemerintah Republik Indonesia Nomor 10 Tahun 1993 Tentang Pelaksanaan UndangUndang Nomor 5 Tahun 1992 Tentang Benda Cagar Budaya 
Presidential Decree Number 12 Of 2009 About Amendment to Presidential Decree Number 19 Year 2007 Concerning Appointment of National Committee and Utilization of Valuable Items originating from Sunken Ships Cargo - Keputusan Presiden Republik Indonesia Nomor 12 Tahun 2009 Tentang Perubahan Atas Keputusan Presiden Nomor 19 Tahun 2007 Tentang Panitia Nasional Pengangkatan Dan Pemanfaatan Benda Berharga Asal Muatan Kapal Yang Tenggelam.

Minister of Transportation's Regulation Number PM $71 \quad$ Year 2013 considering Salvage and/or Underwater Work - Peraturan Menteri Perhubungan Nomor PM 71 Tahun 2013 tentang Salvage dan/atau Pekerjaan Bawah Air.

\section{Cases}

United States of America v. Richard Steinmetz (973 F. 2d 212 - 1992).

Baltimore, Crisfield \& Onancock, Inc., v. United States of America, (140 F. 2d $230-1944)$.

Sea Hunt, Inc. v Unidentified Shipwrecked Vessel or Vessels (221 F.3d 634 2000).

Odyssey Marine Exploration Inc. v Unidentified shipwrecked vessel (No10-1037 - 2011). 